Rural Sociology 0(0), 2022, pp. 1-22

DOI: $10.1111 /$ ruso. 12426

(C) 2022 by the Rural Sociological Society

\title{
The Cows May Safely Graze: Placing Expert-Lay Relationships at the Center of Overcoming the Expert-Lay Knowledge Divide*
}

\author{
Jill Eileen Richardson \\ Department of Sociology \\ University of Wisconsin-Madison
}

Abstract Many scholars agree that both expert and lay knowledge are needed to gain a fuller understanding of environmental problems, both to find answers to the problems and to improve relations between experts and laypeople. When experts ignore lay knowledge, laypeople can resist by accusing experts of arrogance or conspiracy. Rural people who live among large carnivores like wolves and grizzly bears sometimes distrust expert knowledge or even promulgate conspiracy theories. One's knowledge is inextricably linked with one's identity and social relationships. In this ethnographic study, I examine how a Montana-based non-profit, Blackfoot Challenge (BC), facilitates the exchange of knowledge between experts and laypeople for carnivore management. Nurturing expert-lay relationships is one strategy that BC uses in concert with two others to bridge the expert-lay knowledge divide: facilitating learning experiences and relying on intermediaries. Knowledge exchanged within expert relationships allows experts to better understand the needs of laypeople and adapt their work to meet those needs while also disseminating expert knowledge to laypeople in a way that earns their trust. The trust built within expert-lay relationships facilitates the exchange of knowledge, but the way experts and laypeople exchange knowledge also builds trust.

\section{Introduction}

Blackfoot Challenge (BC), a grassroots, landowner-based resource management non-profit, is well-documented as a case of collaborative governance to manage wolves and grizzly bears in Montana (Belsky and Barton 2018; Bixler and Taylor 2012; Weber 2009, 2012; Wilson, Bradley, and Neudecker 2017; Wilson, Neudecker, and Jonkel 2014). Elsewhere in the region and in the world, credentialed experts and laypeopleparticularly laypeople who oppose wolf and grizzly recovery or favor greater use of lethal control-are often at odds with one another over

*Thank you to my advisor, Randy Stoecker, and to Pam Oliver, Samer Alatout, Clark Miller, Sadie Dempsey, Mikki Liu, and Yuliya Nemykina for generously providing me with crucial advice. Thanks to Blackfoot Challenge for making this paper possible in more ways than one. It is a privilege to be able to tell your story. National Science Foundation Sociology Doctoral Dissertation Research Improvement Grant, 2019. Award Number: 1904101. Crowe Scholarship for Grad Student Thesis/Dissertation. 2019. University of Wisconsin-Madison Department of Community and Environmental Sociology. Crowe Scholarship for Pre-Dissertation Research Award. 2018. University of Wisconsin-Madison Department of Community and Environmental Sociology. Address correspondence to Jill Eileen Richardson, Department of Sociology, University of Wisconsin-Madison, 1180 Observatory Dr., Madison, WI 53706, USA. Email: jerichardson@wisc.edu 
what constitutes credible knowledge (Farrell 2015; Robbins 2021; Skogen, Krange, and Figari 2017; Skogen, Mauz, and Krange 2008; von Essen 2017). However, in the seven communities of Montana's Blackfoot watershed (Bonner, Greenough, Helmville, Lincoln Ovando, Potomac, Seeley Lake), BC facilitates collaboration between experts employed by government and as BC staff and laypeople who live, work, and recreate in the watershed (Weber 2009; Wilson et al. 2014).

I bring research explaining BC's achievements into dialogue with literature on human conflicts about carnivores and the role of knowledge in environmental problem-solving. Literature on BC frequently emphasizes the roles of trusting relationships and incorporating both expert and lay knowledge in the organization's success, including in scientists' ability to disseminate scientific knowledge laypeople find credible (Weber 2009; Wilson et al. 2014, 2017). Elsewhere in the United States and Europe, human conflicts about carnivores are often characterized by laypeople and experts disbelieving one another's knowledge (Lute and Gore 2014; Skogen et al. 2017). Literature on the role of knowledge in environmental problem-solving provides a framework to understand how and why an "expert-lay knowledge divide" occurs, as well as the connection between social relationships and knowledge (Bell 2004; Wynne 1992, 1996). Past research has described BC's incorporation of both expert and lay knowledge and the role trusting relationships play in their success, but researchers mostly examined the two ideas separately. I extend their work by exploring both ideas together and connecting them back to the broader literature on public participation and expertise. How do expert-lay relationships facilitate BC bridging the expert-lay knowledge divide?

Drawing on participant observation and interviews with people who live, work, and recreate in the Blackfoot, I find BC board and staff and employees of partnering government wildlife agencies, Montana Department of Fish Wildlife and Parks (FWP), and U.S. Fish and Wildlife Service (FWS), use expert-lay relationships in tandem with two other strategies that facilitate experts and laypeople communicating knowledge effectively enough to collaboratively manage wolves and grizzly bears and keep people safe. First, BC's board and staff and employees of partnering government agencies facilitate learning experiences in which Blackfoot residents can observe and draw their own conclusions. Second, experts and laypeople built trust within relationships, facilitating both sides' communication of knowledge to the other. Last, BC and its government partners strategically employ people who have already earned the relevant parties' trust to serve as intermediaries between those who lack a pre-existing trusting relationship. 


\section{Lit Review}

\section{The Expert-Lay Knowledge Divide}

An interdisciplinary body of literature advocates including lay knowledge alongside expert knowledge in solving environmental problems for the value of the knowledge itself (Collins and Evans 2002; Kloppenburg 1991), the empowerment of the holders of lay knowledge, or to reduce lay distrust in expert knowledge. None advocate forgoing expert input in public decision making-and some are anxious about being too inclusive of knowledge, lest conspiracy theories are treated as equally valid as scientific consensus (Collins and Evans 2002) - but all agree that expert knowledge alone is insufficient.

Within this literature, terminology differs, and none of the terms available are entirely unproblematic. Laypeople are often referred to as locals and citizens. I use "lay," defined as "non-professional, not expert" (OED Online), as a mutually exclusive term to contrast with credentialed "experts." Scholars sometimes use the term "scientists" interchangeably with "experts" when the type of expertise in question is science. Contrasting "laypeople" and "experts" overlook the value and depth of laypeople's knowledge, which is not my intention. Rather, I refer to the way the two groups are socially constructed and how they interact with social institutions and with one another. In this rendering, experts have formal credentials (e.g., a college degree) and professional positions that confer power and portable social recognition of their knowledge within the dominant culture which laypeople lack, even when laypeople's knowledge is extensive.

Knowledge is socially negotiated; it cannot be separated from the humans who produce it and their places in the societies they live in (Haraway 1988; Irwin 1995). My research interest is neither to produce "true" knowledge about carnivores nor to adjudicate between experts and lay knowledge, which is more or less true and by how much. My interest is to (1) underscore the importance of the social constructedness of all forms of knowledge, but also (2) to open up the ways (when, how, under what pressures) lay and expert knowledge are negotiated and settled. Therefore, I take a constructivist view of knowledge, defining knowledge as what people believe is true (Skogen et al. 2017).

As noted above, one reason to include both expert and lay knowledge in decision-making is to help reach better answers. Knowledge gained from multigenerational lived experience in a particular place and time is a necessary complement to universalized, decontextualized scientific knowledge (Weber et al. 2014). Without lay input, scientists can make mistakes when they evaluate questions based on inaccurate assumptions 
of real-world conditions (Irwin 1995). For example, when scientists failed to incorporate Cumbrian sheep farmers' knowledge of sheep grazing while trying to determine how to respond to the radiation released by the Chernobyl disaster, scientists reached an inaccurate conclusion (Wynne 1992, 1996). In California, scientists assess pesticide safety assuming perfect usage conditions without consulting the knowledge of farmworkers familiar with actual usage conditions (Harrison 2011). The inaccurate assumptions lead to safety guidelines that result in pesticide poisoning under real-world conditions.

These examples also point to power asymmetries between experts and laypeople. Some call for including lay knowledge in public decision-making because excluding laypeople from providing input in decisions that affect their lives violates the principles of democracy (Nelkin 1975) and provides opportunities for abuse by the wealthy and powerful (Gordon 2021; Haraway 1988; Harrison 2011; Irwin 1995; Krings, Kornberg, and Lane 2019; Smith 2012). As noted by Foucault (1977:184), "the deployment of force and the establishment of truth" are one and the same: knowledge cannot be separated from power. Power is "the probability that one actor within a social relationship will be in a position to carry out [their] own will despite resistance" (Weber 1978:53). In some cases, experts can be co-opted to legitimize powerful interests while marginalizing the knowledge of non-experts-even those with relevant specialized knowledge (Harrison 2011; Irwin 1995; Krings et al. 2019).

Exclusion of lay knowledge in solving environmental problems can also result in lay disbelief of expert knowledge, with laypeople accusing scientists of inaccuracy due to conspiracy or arrogance (Skogen et al. 2017; von Essen 2017; Wynne 1992). Others believe lay distrust of experts stems from "the institutional neglect of issues of public meaning, and the presumptive imposition of such meanings (and identities) on those publics and the public domain" (Wynne 2003:402). Each person's knowledge contributes to their identity (Bell 2004; Hassanein and Kloppenburg 1995; Wynne 1992, 1996). One's identity as a rancher, a hunter, or a wildlife biologist rests on a wealth of knowledge about ranching, hunting, and wildlife biology, respectively. Returning to the previous example of Cumbrian sheep farmers, scientists threatened the sheep farmers' identities as holders of specialized knowledge by failing to consult sheep farmers' knowledge.

Whereas some explain lay disbelief of expert knowledge with identitybased theories, others rely on power-based theories. In human conflicts about carnivores in the U.S. and Europe, both laypeople and experts 
often attempt to present their knowledge as scientific, while simultaneously attempting to delegitimize their opponents' claims as "emotional" or "barstool biology" (von Essen 2017; Robbins 2006). ${ }^{1}$ Laypeople often dismiss expert knowledge as politically motivated, even accusing government scientists of lying (Browne-Nuñez et al. 2015; Lute and Gore 2014; Skogen et al. 2017). In Europe, when scientists dismissed laypeople's lived knowledge about carnivores, laypeople resisted by circulating conspiracy theories, like accusations that the government is secretly importing wolves from abroad or lying about the number of wolves (Skogen et al. 2017). In an email, Skogen noted that the same occurs in the United States. ${ }^{2}$ Some explain lay distrust of expert knowledge as resistance by people who feel they are marginalized (Skogen et al. 2008; von Essen 2017).

\section{Bridging the Divide}

Collaboration between laypeople and experts requires all parties to practice reflexivity, situating their own knowledge in their experiences and finding links to others' knowledge situated in others' experiences (Ashwood et al. 2014). An unquestioning belief that one's own knowledge and way of knowing is the truth and all others are wrong prevents one from communicating effectively with those who do not share one's positionality (Ashwood et al. 2014; Irwin 1995). Practicing reflexivity requires recognizing that science is not a value-free, neutral, objective endeavor independent of all social forces, and abandoning the belief that "any problematic relationship between science and citizens must be a consequence of either public ignorance or public irrationality" (Irwin 1995:15).

To bridge the expert-lay knowledge divide, scholars often recommend participatory processes (Fiorino 1990). Participatory processes can promote "building democratic skills, overcoming feelings of powerlessness and alienation, and contributing to the legitimacy of the political system" (Fiorino 1990:229). However, efforts to incorporate lay knowledge into participatory community natural resource management do not always succeed (Kellert et al. 2000). Literature on carnivore management, discussed below, provides contrasting examples of experts and laypeople communicating knowledge to one another successfully and unsuccessfully.

\footnotetext{
${ }^{1}$ The exceptions are Indigenous people who assert the legitimacy of Indigenous knowledge to be incorporated in decision-making alongside scientific knowledge (Affiliated Tribes of Northwest Indians et al. 2021).

${ }^{2}$ Ketil Skogen, email to author, January 10, 2018.
} 
BC, a landowner-driven community-based natural resource management non-profit organization in Montana's Blackfoot watershed, is widely recognized for its longstanding success using participatory methods and incorporating both expert and lay knowledge to solve environmental problems, including carnivore management (Weber 2009; Wilson et al. 2014, 2017). BC frames its work as serving the shared interests of the community, incorporating natural science, social science, and lay knowledge in its approach (Weber 2009). Past research explaining BC's achievements points to multiple forms of sharing and producing knowledge among and between experts and laypeople: a neighbor-toneighbor phone tree, regular meetings and written reports, and participatory research (Wilson et al. 2014). However, as noted above, knowledge sharing alone is not sufficient to bridge the expert-lay knowledge divide. Efforts at carnivore management are often complicated when laypeople and experts disbelieve one another's knowledge.

Research on BC names the organization's past participatory research projects as crucial for overcoming the expert-lay divide by reversing the usual flow of information, with laypeople educating experts (Weber 2009; Wilson et al. 2014) In participatory research, experts and laypeople generate new knowledge together. However, a comparison between one of BC's participatory research projects—a participatory wolf count-and a participatory lynx count in Norway illustrates that experts can derail attempts to incorporate lay knowledge via participatory research. In Norway, experts used statistical methods to count lynx that only looked for animals in a sample of locations, refused to look for the animals where laypeople knew them to be, and distrusted the reliability of lay reports of lynx sightings (Skogen et al. 2017). In BC's participatory wolf count, experts provided laypeople with information and documentation tools that allowed their reports to be credible to experts (Wilson et al. 2017). Lay participation only improved expert-lay relations when experts valued lay knowledge instead of disregarding it.

Knowledge is embedded in social relationships, and relationships serve as the basis for the trust people have (or do not have) in one another's knowledge (Bell 2004; Wenger 2000; Wynne 1996). One cultivates knowledge from sources and ways of knowing trusted by the group one identifies with (Bell 2004). Three experts in leadership in BC's grizzly bear program wrote that $\mathrm{BC}$ and its partners "develop trusting relationships for sharing information," tying trusting relationships to the ability to share information (Wilson et al. 2014:190). Belsky and Barton (2018) also connect knowledge to relationships, pointing out $\mathrm{BC}$ participants strengthen their relationships with one another while they focus on areas of agreement and slowly gather data together, engaging in "incremental 
learning." BC refers to its approach of focusing on areas of agreement as to the " $80 / 20$ rule," focusing on the estimated 80 percent the group can reach consensus on while setting aside the 20 percent for which they disagree (Belsky and Barton 2018). After time has passed, with more shared knowledge and stronger relationships, BC can reach consensuses on issues that previously sparked disagreement.

Trusting relationships play a large role in BC's accomplishments. Ranchers and government scientists in leadership in BC reported initially distrusting one another and developing trusting relationships with one another over time (Weber 2009, 2012). Past studies attribute laypeople's increased trust in experts in BC to experts adopting laypeople's framing of the problem; focusing on areas of consensus like the desire to protect human life and reduce livestock depredation and setting aside areas of disagreement; offering landowners programs that immediately met their needs (Belsky and Barton 2018; Wilson et al. 2014). BC often relies on pre-existing trusting relationships, seeking out Blackfoot community "elders" to serve as influencers to sway others in the community or hiring members of respected ranch families as range riders (Weber 2012; Wilson et al. 2014, 2017). Given the embeddedness of knowledge in social relationships and BC's reliance on trusting relationships in its work, how do expert-lay relationships facilitate BC bridging the expertlay knowledge divide?

\section{Methods}

This study was conducted as one part of my larger research agenda over three years of digital and in-person ethnography on conflicts between humans over wolves, grizzly bears, and elk in Montana. I lived in Montana, both in Missoula, the city closest to the Blackfoot, and in the Bitterroot valley, from June 2, 2019 to August 27, 2019, and returned for an 11-day trip the first of November 2019. During the November trip, I stayed in Ovando, in the center of the Blackfoot. During that time, I attended BC board and staff meetings, public events, and public meetings in the Blackfoot, and conducted 29 semi-structured interviews lasting one to three hours with 27 participants who live in the Blackfoot or work in the Blackfoot for BC, FWS, or FWP.

BC board and staff members recommended a list of people to interview and, through snowball sampling, I identified and interviewed people not on the provided list, aiming to hear a wide range of opinions in the valley, including a mix of genders, occupations, political views, experiences with wildlife, and relationships to government and BC. Interviewees included 19 men and 7 women; 8 current and past BC board members, 4 staff members, and 4 committee members; 7 government 
employees (FWS and FWP); ranchers (both landowners and land managers), hunters, trappers, residents who neither hunt nor ranch, land managers for properties of absentee or part-time resident landowners, and no absentee landowners or part-time residents. (Some participants hold more than one of these identities.) One interviewee was a Native American and the remainder were white. Although BC represents the geographic area of the watershed, I define my study area as the seven municipalities in the watershed because I relied on maps denoting town boundaries rather than watershed boundaries while conducting fieldwork. Interviewees lived in Greenough (6), Helmville (4), Lincoln (1), Ovando (7), Missoula (6), Potomac (1), and Seeley Lake (2). Those who lived in Missoula worked or recreated in the Blackfoot.

I categorized wildlife experts as people with a college degree (or higher) in wildlife biology or other natural resource fields who are employed in a professional job where they work with wildlife using knowledge from their academic training. This group comprises all participating government employees (some of whom serve on BC's board and some who do not) and many BC staff members. Laypeople are, broadly speaking, the people the experts are employed to serve: Blackfoot residents who do not meet the criteria of expert defined above who interact with wildlife in daily life on land they own, rent, or manage. Two people in this category have college degrees in natural resource fields, but do not work in professional jobs managing wildlife.

Interviews were minimally structured. I began by asking each participant if they were originally from Montana, which usually resulted in a story about how they or their ancestors came to Montana and a chronological account about their relationship with the land. Participants knew I was studying wolves, grizzlies, and elk, and I let them tell me their stories, directing them as little as possible, but often asking follow-up questions based on their answers. Interviews focused on the interviewees' experiences with carnivores and with BC and government over time, both past and present, including what they knew about carnivores, how they knew it, who they learned from, whose knowledge they trusted or distrusted (and why), and how experts and laypeople felt about their relationships with one another. I audio-recorded and transcribed all interviews and public meetings and events and took field notes at $\mathrm{BC}$ meetings and events.

I conducted interviews until saturation, the point when new data conforms to the researchers' expectations and does not contribute new knowledge (Small 2009). This occurred fairly quickly in the Blackfoot both because of the abundance of data available and the consistency of the data. I was frequently able to triangulate data from interviews and 
participant observation with written sources like online articles, websites, and government data. Many interviewees knew one another, so I frequently heard multiple accounts of the same story from different perspectives.

I coded all transcriptions, field notes, documents, and other data in MAXQDA software. I focused on knowledge and relationships: Who did people name as trustworthy? Who do they distrust, and why do they say they distrust them? How did people determine who was trustworthy? I coded for how people learned, who they learned from, and how they positioned their knowledge as credible to others. All names are pseudonyms.

\section{Results}

The study found that relationships between people-expert and laywere at the core of BC's ability to bridge the expert-lay knowledge divide, in addition to facilitating learning experiences and relying on intermediaries. This work was largely initiated by both experts and laypeople on BC's board, staff, and committees and by government employees who work with Blackfoot residents directly and through BC. First, they facilitated learning experiences for Blackfoot residents, allowing them to draw their own conclusions from observations and experiences instead of telling them what to believe. Second, laypeople and experts built relationships with one another over time and their relationships facilitated the transmission of knowledge. Third, people who already trusted one another served as intermediaries for those who did not yet have trusting relationships (Figure 1 ).

All three strategies-facilitating learning experiences, building relationships, and using intermediaries-provide both experts and laypeople with information from sources they find credible while allowing them autonomy in determining what they believe is true. By doing so, these strategies facilitate the exchange of knowledge between experts and laypeople to allow for collaboration. While $\mathrm{BC}$ and its government partners were neither instantaneously nor universally successful in eliminating disputes over "what is true" or preventing all property damage and depredation by carnivores, they agreed enough on what was happening and what needed to be done to develop programs informed by both lay and expert knowledge, increasing participation in those programs over time, and decreasing human-carnivore conflicts.

\section{Facilitating Learning Experiences}

The first strategy, facilitating learning experiences, was articulated most clearly by a rancher and a government employee who worked together in BC leadership for many years. They both attributed the idea to facilitate 


\begin{tabular}{|c|c|c|c|}
\hline & Example & Trust & Knowledge \\
\hline $\begin{array}{l}\text { Learning } \\
\text { Experiences } \\
\text { Communicate } \\
\text { knowledge by } \\
\text { showing } \\
\text { instead of } \\
\text { telling. }\end{array}$ & $\begin{array}{l}\text { Government shows } \\
\text { BC ranchers GPS } \\
\text { data for two bears; } \\
\text { ranchers learn that } \\
\text { bears lived among } \\
\text { them undetected for } \\
\text { a summer. }\end{array}$ & $\begin{array}{l}\text { Minimum needed. } \\
\text { Ranchers only need to } \\
\text { trust the validity of the } \\
\text { GPS data. }\end{array}$ & $\begin{array}{l}\text { Produces shared } \\
\text { knowledge. } \\
\text { Both government \& BC } \\
\text { ranchers know that bears } \\
\text { don't always cause } \\
\text { problems when they live } \\
\text { nearby. }\end{array}$ \\
\hline $\begin{array}{l}\text { Expert-lay } \\
\text { relationships } \\
\text { Form trusting } \\
\text { long-term } \\
\text { relationships. }\end{array}$ & $\begin{array}{l}\text { BC's board is led } \\
\text { by a rancher and an } \\
\text { FWS employee. } \\
\text { Beca considers the } \\
\text { wildlife experts } \\
\text { friends she sees at } \\
\text { social activities and } \\
\text { she texts. }\end{array}$ & $\begin{array}{l}\text { Increased/High. } \\
\text { Experts and lay people } \\
\text { work closely together } \\
\text { for years and place a } \\
\text { high value on their } \\
\text { relationship. They } \\
\text { express gratitude for } \\
\text { one another. }\end{array}$ & $\begin{array}{l}\text { Exchanges knowledge. } \\
\text { Both experts and lay } \\
\text { people share what they } \\
\text { learned from one another } \\
\text { and how it helps them } \\
\text { manage carnivores. Those } \\
\text { who work in government } \\
\text { and BC practice } \\
\text { reflexivity. They report } \\
\text { actively working to } \\
\text { improve and maintain } \\
\text { trusting relationships. }\end{array}$ \\
\hline $\begin{array}{l}\text { Intermediaries } \\
\text { When experts } \\
\text { and lay people } \\
\text { do not have a } \\
\text { pre-existing } \\
\text { trusting } \\
\text { relationship, an } \\
\text { intermediary } \\
\text { can broker } \\
\text { communication } \\
\text { between them. }\end{array}$ & $\begin{array}{l}\text { A BC staff person } \\
\text { sees Aubrey's post } \\
\text { about bears on } \\
\text { Facebook and gives } \\
\text { her a government } \\
\text { employee's phone } \\
\text { number. He } \\
\text { responds the same } \\
\text { day along with } \\
\text { BC's wildlife } \\
\text { coordinator and a } \\
\text { rancher in BC she } \\
\text { has known for } 20 \\
\text { years. }\end{array}$ & $\begin{array}{l}\text { High. } \\
\text { Relies on social } \\
\text { networks of people } \\
\text { who already have } \\
\text { trusting relationships: } \\
\text { family, friends, } \\
\text { neighbors, ranchers to } \\
\text { other ranchers, hunters } \\
\text { to other hunters, people } \\
\text { who work in businesses } \\
\text { in town to customers, } \\
\text { etc. }\end{array}$ & $\begin{array}{l}\text { Translates and } \\
\text { Disseminates Knowledge. } \\
\text { By posting on Facebook, } \\
\text { Aubrey was quickly } \\
\text { connected with the } \\
\text { knowledge (and } \\
\text { resources) she needed to } \\
\text { protect her property from } \\
\text { bears. Expert-lay } \\
\text { relationships form a hub, } \\
\text { and social networks in the } \\
\text { Blackfoot form the } \\
\text { spokes. }\end{array}$ \\
\hline
\end{tabular}

Figure 1. Summary of Results

learning experiences to a former executive director of BC, a clinical psychologist. The government employee described how the former executive director explained it to him:

He said, 'They need to have an affectual experience, an experiential experience that they then get it. So, that's probably not going to come from you telling them what the issue is... It's probably going to be from them talking to their neighbor or having an experience on their own place. One example is, can you develop a water source, a well development, to help pull livestock away from a stream? Then can you put in a stock watering tank away from the creek, but don't do any fences on the stream, you just allow the cows to use it. Hopefully the landowner goes, "Oh, my gosh, they 
like that water from the well better than they like the water from the stream. It's colder in the summer, it's cleaner water and they're not standing in the stream anymore." All of a sudden, the cows start spending more time away from the stream and the stream starts to recover a little bit and that's an affectual experience. That's what you need to work on.' And that was inspirational for me in thinking about that whole mindset of how do we get other people to work together as a team? It's not us educating them. It's giving them an experience that they go 'Oh I get it.'

Both experts and laypeople within BC's board and staff facilitate opportunities for Blackfoot residents to have experiences that allow them to learn by observing and drawing their own conclusions. For example, in response to feedback from residents that residents disliked opening and closing electric fence gates, BC installed electric drive-over mats (mats with an electric charge that allow vehicles to enter a fenced area but exclude carnivores) on several ranches in the Blackfoot. They also installed game cameras to record footage at a test location and showed the video at a board meeting in which grizzly bears and a mountain lion tried to get through the mat to get a deer carcass but could not.

Instead of telling laypeople that experts did a study and the mats work, $\mathrm{BC}$ 's wildlife coordinator allowed everyone to evaluate the data themselves in a format the people found credible. Watching the video together was entertaining, with a lot of commentary and laughter as the group watched each animal try to get through the mat and fail. BC showed rather than told that carnivores cannot cross the mats because of their electric charge, but they allowed those who saw the video to draw any conclusion they wished.

For ranchers and other Blackfoot residents, the decision to adopt a technology like the mats rested on more than knowledge of the technology's effectiveness. In interviews, residents justified their decisions to install electric fences (or not) with knowledge of whether their property or livestock was susceptible to conflicts with carnivores and knowledge of whether fences would fit into their day-to-day operations and budgets. One rancher said he had not installed a fence because it is an expensive initial investment and, so far, his area had not experienced conflicts with carnivores. Several other ranchers had not installed fences because fences were incompatible with their ranches' operations. The test captured on video did not show how a mat might fit into a ranch's operations. However, by installing mats on several ranches in the Blackfoot, $\mathrm{BC}$ and its partners are allowing those ranchers to learn about the everyday experience of using the mats. By facilitating shared learning experiences, $\mathrm{BC}$ and its government partners allow experts and laypeople to 
construct a shared (enough) reality to improve carnivore management by producing new knowledge together or by offering information in a way that minimizes the amount of trust those involved must have in one another to find the information credible. This strategy works in concert with the other strategies below and often serves as a basis for building trust, allowing laypeople to validate expert knowledge through their own experiences and observations and to translate it into a form that is most useful in their own lives.

\section{Forming Trusting Relationships}

The second strategy this study found as a key in negotiating the knowledge divide is forming trusting relationships. The study found that experts in BC's board and staff and employees in partnering government agencies form trusting relationships with some lay Blackfoot residents within BC and outside of it, and they communicate knowledge within those relationships. Interviewees described trusting relationships as relationships in which both parties act in ways the other does not consider a violation and respond to amend the breach if a violation occurs. While it is not the case that every layperson in the Blackfoot has a trusting relationship with every expert, those who do serve as a conduit for exchanging and disseminating knowledge between social groups, and (as discussed below), often serve as intermediaries. Additionally, sharing knowledge with one another builds their trust and strengthens their relationships.

BC offers a venue in which people can become acquainted or develop a relationship over time. BC's board and committees include both laypeople and experts representing a variety of stakeholder groups including ranchers and other landowners, outfitters, foresters, conservation groups, and a number of government agencies with jurisdiction over natural resources in the Blackfoot including FWP and FWS. The staff are mostly credentialed professionals ("experts"), although some have expertise in areas other than wildlife (such as finance, forestry, or botany). BC allows laypeople and experts to work together and spend time together socially, but it places enough laypeople in leadership roles (including as board chair and as chairs of most committees) that experts cannot dominate. The board's consensus-based decisionmaking also ensures that all decisions reflect the wishes of the entire board. BC's board meetings are open to the public and they also hold several public events each year, such as trumpeter swan releases and a block party. As many of these events are informal and social, they provide opportunities for participants to establish and deepen relationships across social groups. Both experts and laypeople who participate or work with BC said they felt these trusting relationships contribute 
to their ability to collaborate and frequently referenced learning from one another.

Several interviewees (both laypeople and experts) described exchanging knowledge as a reciprocal process in which the amount of laypeople listen to and trust experts is contingent upon experts listening to and trusting laypeople. For example, when one government employee (who other government employees cited as a mentor) spoke about how to develop and maintain trust with Blackfoot residents, he said:

Ask them questions versus saying things... If I said, 'How your cows doing?' and then they told me, it allowed them to talk and get comfortable and also it allowed me not to stick my foot in my mouth.

In this case, he referred to learning from ranchers about a subject for which ranchers hold specialized knowledge that he lacks: cows. Asking questions and listening allows him to learn more about residents' needs so he can address them better, like learning that some residents find electric fences ugly and responding using shorter electric fences and placing a second, more attractive fence inside them. He gave a second example of a situation in which lay knowledge and expert knowledge conflicted, connecting invalidating a layperson's knowledge-even when one believes the layperson is inaccurate-to sabotage a relationship with that person and their neighbors:

In the early days of the Range Rider Program, one of our range riders was told by a landowner that they saw a wolf. The ranger rider went out, looked for tracks, and believed what the landowner saw was a coyote. He told the landowner that it wasn't a wolf, it was a coyote. That seems pretty innocent, but it was probably the wrong thing to do. In the big scheme does it really matter whether it was a wolf or a coyote? ... A more productive response should have been, 'OK, thank you' and report that information that this... landowner ... saw this wolf in this area? It wasn't a scientific paper so no harm no foul. Instead what happened was the landowner who reported the wolf and was told it wasn't a wolf told his neighbors that the range rider didn't respect his opinion and didn't trust him. That single incident had far reaching negative impacts to our relationships than all of our other missteps along the way.

In this case, he makes it clear that receiving the lay person's knowledge graciously was important for building a relationship with them, whereas his belief in the accuracy of the knowledge was relatively unimportant (but 
would be important in other circumstances, like writing a scientific paper). He also said, "I don't care whether people believe in climate change or not... Are you willing to do something about it?" He prioritized laypeople's willingness to take actions in line with his agency's goals above their agreement with his agency's understanding of "the facts."

A few laypeople also reported distrust in experts from FWP because they felt the experts did not listen to them. Several government employees (including one from FWP) said it is important to avoid losing laypeoples' trust and make amends when incidents like this that lose laypeople's trust occur. An example a BC staff person provided is how carefully BC guarded the confidentiality of participants in its carcass removal program because sharing their identities would violate their trust. Both experts and laypeople described the importance of building trust over years and consistently working to not lose it.

One rancher described an incident that shows another way experts and laypeople gained more trust in one another: when experts share knowledge to increase transparency and laypeople prove they can be trusted with that knowledge. When the government biologists tracked two grizzly bears over a summer, they initially did not want to share the data with landowners. Landowners insisted, and the government biologists reluctantly shared the data. This provided both sides with a learning experience: landowners saw evidence that two grizzlies had lived among them, undetected, for an entire summer, concluding (in the rancher's words) "Oh well, maybe we can live with these bears if they behave themselves," and the government biologists saw ranchers could be trusted to use the data responsibly (e.g., they do not share it with anyone who might use it to kill carnivores).

Both experts and laypeople said their relationships with one another were beneficial to laypeople's ability to learn from experts. In interviews, experts spoke about their relationships with laypeople as a part of carrying out the social functions of their jobs. A BC staff person said, "It's worth me spending some time here [a restaurant in the Blackfoot] every now and then just to get to know people, right? Being part of the community, folks get to trust you and yeah, it makes a difference." In restaurants or events in the Blackfoot, one can regularly see BC board and staff and government employees (particularly those who live in the Blackfoot) socializing with other Blackfoot residents. In interviews, ranchers frequently referred to individual government employees as "my good friend" or "awesome." A rancher named Beca said:

A lot of those folks within both FWP and the Challenge, they're friends. You know we're at each other's kids' soccer games. We're meeting for a drink at the bar... At this stage in 
the game... it's really just like a text or a quick conversation or a 'hey we had this come up what do you think we ought to try doing with it?' But those relationships wouldn't work like that had it not been a lot of times across the table listening to how everybody operates.

Beca spoke about BC and FWP wildlife staff as helpful experts who can provide her with new knowledge to help her make decisions:

Part of it is you start really-you get exposed to all these great thinkers and big thinkers and different perspectives. And it makes you pause quite a bit more before you're making decisions on things. And that's good, right?... We consult the experts. We work closely with [BC's wildlife coordinator] and [the person] who manages our mountain lion population for FWP. We talk to those guys pretty darn regularly. They're very up to speed on all the going-ons. We're making plans with them. They're experts in their field. Try and default to what they're doing so long as we can keep our folks on property safe.

Like Beca, in their narratives during interviews, landowners and land managers framed themselves as competent managers who continually took in new information as it became available and solved problems as they arose or as solutions became available. Except for the few interviewees who distrusted FWP, most laypeople interviewed spoke about experts from BC, FWP, and FWS as helpful, casting them in a consulting role in their narratives as Beca did above.

In interviews, all of the experts said they aimed to share their own knowledge when it would be welcome-and in ways, it would be welcomed. Beca shared how much she values this in BC's wildlife coordinator:

He's not pompous. And that makes him... a go-to person to approach. Because... when I'm having some type of situation on the property that's stressful, the last thing I want to do is have some like pompous person with a bunch of bravado telling me all the things that we've done wrong.

Whereas offering learning experiences minimizes the interpersonal trust needed to convey knowledge, communicating knowledge within relationships relies on trust already present. These two strategies can support one another, as knowledge from lived experience can support the credibility of knowledge learned from a person one trusts, and vice versa. As shown in the examples above, building trust requires treating one another as each person wishes to be treated, which may require 
withholding unwanted information or sharing knowledge in a way that is more palatable to the recipient. Laypeople who have trusting relationships with experts can serve as effective intermediaries to other laypeople, discussed in the next section.

\section{Using Intermediaries}

To collaborate with people who do not yet (and may never) have trusting relationships, the BC board and staff and their partners in government often rely on laypeople who have pre-existing relationships with other laypeople BC wishes to reach. This strategy allows laypeople who do not have strong relationships with experts themselves to learn from laypeople who do. One government employee said, "The ranchers are now our voice. And are you know, encouraging other ranchers to follow their lead. And approach living in grizzly country like they have." One way $\mathrm{BC}$ and its government partners did this was by placing the drive-over mat on ranches; ranchers interested in learning more about the mats can learn about them from ranchers already using them. The ranchers already using the mats can serve as intermediaries, sharing knowledge that experts cannot: first-hand knowledge of lived experience using the mats on a working ranch.

Knowledge about carnivores spreads through social networks in the Blackfoot. In interviews, family members spoke about one another's experiences with carnivores, neighbors spoke about neighbors, and friends spoke about their friends. Businesses and restaurants in the Blackfoot serve as social hubs, and carnivores are such a hot topic that a few business owners keep photos they took of grizzly bears behind the counter to show anyone who stops by. A government employee and four different ranchers all spoke about the first ranch that installed an electric fence after suffering grizzly depredation when grizzlies first returned. Intermediaries can also translate knowledge from a form someone will not hear it into the one that they will. For example, Ray has poor relationships with FWP employees and with many on BC's board, but he is friends with Dave, who is active in $\mathrm{BC}$ and can serve as an intermediary between Ray and BC. Due to Dave's urging, Ray decided to begin participating in one BC carnivore management program while continuing to mostly keep his distance from BC and FWP. In interviews, laypeople were clear that they did not automatically adopt the knowledge of those they had relationships with as their own (sometimes they would share what a friend or neighbor believed that they did not think was true). However, as was the case for Ray, relationships were one avenue through which learning took place, and it was one that BC frequently used. 
Sometimes the intermediary stays with the people who do not know each other (or know each other well) to help ease things between them. This can be as simple as having a prominent rancher from a town introduce a government speaker at a meeting in that town where many attendees are ranchers. Aubrey's story illustrates how BC and its government partners use intermediaries to help foster new relationships and exchange knowledge. After grizzly bears damaged Aubrey's unsecured property, she posted about it on Facebook. A neighbor employed by BC responded quickly, giving her the phone number of the government employee who would respond. Aubrey recalled that the same day:

[BC's wildlife coordinator, who she knew] showed up first and [he] said, we're going to put you up some... electrical fence, him and [a rancher in BC leadership]... And then [an FWP biologist, who she did not know] came up and tried to get some hair samples and stuff off of it [the bear] for them, to see what it was... And he [the biologist] was the one that informed me a lot about bears... [BC's wildlife coordinator] was super informative, and kind of fun. I was his little assistant for the next few days, we drove... a deer carcass all around my yard. And we set up a bear trap right over here in the field. And I was going to be the one to check the trap every day. And he taught me about the trap and how to lock that trap if there was a bear in there.

In addition to commenting on how both experts taught her about bears, Aubrey also emphasized how fun the experience was. She connected her comfort with the rancher, acting as an intermediary, to their pre-existing relationship:

It was really kind of funny... because... [the rancher] went to test the fence... and he touched the fence... Knocked him on his ass. Oh, I about died peeing my pants laughing. [BC's wildlife coordinator] didn't dare laugh. He was, like, straight faced and I lost it, laughing... Then [BC's wildlife coordinator] started laughing and goes, 'I wasn't going to laugh until you laughed and I knew it's OK.' It's like, that's-I've known [the rancher] for like 20 something years.

Instead of interacting only with a biologist from the city she had never met before, Aubrey had two people she knew and liked, including a very old friend, present to make the experience more enjoyable. Following this, Aubrey became a well-informed outspoken advocate for 
bear safety, sharing the knowledge she learned from both experts with other Blackfoot residents (now serving as an intermediary herself).

\section{Limitations to BC's Approach to Bridging the Knowledge Divide}

Despite the three strategies discussed above, BC's success with integrating lay and expert knowledge has limitations. There are still laypeople in the area who believe misinformation about carnivores that leaves them vulnerable to conflicts with carnivores and which BC's strategies have not yet overcome. For example, Aubrey, who is not originally from Montana, asked Montanan neighbors about bears, and-although one person insisted that she was not practicing sufficient bear safety—she believed others who told her there was no reason for concern. Several years without a bear incident led her to believe their knowledge was reliable until one day grizzly bears proved otherwise. One government employee pointed out that years of living among wildlife without taking precautions and without incidents can reinforce the belief that precautions are not needed.

Even now, when Aubrey shares the testimony of her experience to convince others that they should not leave food where bears can get it, she says many do not listen:

Interviewer: "Do you think there's still a lot of people around that [leave their property susceptible to bears]?"

Aubrey: "Oh, absolutely, 100\%."

Interviewer: "So they didn't learn from it happening to you?"

Aubrey: "Not at all. But a lot of people say it's because I'm on this side of town. [Sarcastically] Yeah, it makes it different."

Some laypeople cannot be deterred from believing that they do not need to protect human sources of food from wildlife (or even that it helps wildlife when humans feed them, as two interviewees did). I still observed birdfeeders accessible to grizzly bears in a location where the landowner had seen a grizzly before. Experts and many laypeople say both practices can place humans and animals in danger. Other laypeople believe the only way to manage carnivores is by killing them or, conversely, that carnivores can be managed without killing any of them, whereas experts and many laypeople believe non-lethal carnivore management is effective but "problem" animals must be removed. In short, although the Blackfoot is home to many laypeople who partner effectively with experts, it is also home to people who do not, impeding universal participation in BC and government carnivore management programs. BC's board and staff and employees of partnering government agencies work 
toward continuous progress in experts and laypeople reaching a shared enough body of knowledge to manage carnivores effectively together.

Additionally, the transferability of these three strategies may be limited. This is because the Blackfoot is shielded from several common sources of social tensions. The area is more than $90 \%$ white, limiting the potential for racial or ethnic conflict (Census.gov). The Blackfoot is several hours from any national park and the wolves in the area were not reintroduced, shielding them from other sources of controversy. Unlike the nearby Bitterroot Valley because of the early formation and successful work of BC, including extensive land use planning, and conservation easements, among other factors, the Blackfoot avoided development from a rapidly growing population that exacerbated the social conflict. That does not mean that their strategies will not work in other areas, but they may be less effective where there are additional challenges.

\section{Discussion and Conclusion}

BC used three strategies to integrate expert and lay knowledge: facilitating learning experiences, forming trusting relationships, and relying on intermediaries. These strategies, respectively, communicate knowledge in ways that minimize the amount of trust needed; work to increase the amount of trust between experts and laypeople (within and between groups), or rely on pre-existing trusting relationships among laypeople.

This study's findings are compatible with both identity- and powerbased theories of lay disbelief in expert knowledge. All three strategies together avoid experts imposing meaning on laypeople or threatening laypeople's identities as holders of specialized knowledge, which past research suggests can result in lay distrust in expert knowledge (Wynne 1992, 1996). Instead, these strategies allow laypeople to adopt knowledge as their own when, if, and how they see fit while altering circumstances to increase the likelihood that laypeople do so. They also allow laypeople the freedom to reject expert knowledge, and some do. During my fieldwork, I never heard anyone in the Blackfoot endorse (or even mention) conspiracy theories about carnivores, which power-based theories interpret as a form of cultural resistance by people who feel marginalized (Skogen et al. 2008).

One's knowledge is enmeshed with one's social relationships as well as one's identity (Bell 2004), and BC's use of relationships to communicate knowledge may also be compatible with both identity- and power-based theories. One's trust in knowledge may hinge on the perceived trustworthiness of the person or institution communicating that knowledge (Irwin 1995). By building trust over time within one-on-one relationships, participants in BC learn about one another, 
including how one another wishes to be treated. This may reduce the likelihood experts threaten laypeople's identities or power and allow them to respond quickly if they do. Relationships may also increase people's abilities to situate and link their knowledge (Ashwood et al. 2014), as they get to know the context of one another's lives over time. Future research should explore how, specifically, relationships facilitate knowledge exchange, and in what circumstances relationships fail to facilitate knowledge exchange.

Future research should also explore the transferability of BC's approach. Can this approach be scaled up beyond the level of the watershed or to places with larger populations? Is this approach transferrable in places facing racial or ethnic conflict or where multinational corporations have more influence than they do in the Blackfoot? Could this approach work in an area where there is initially greater distrust between experts and laypeople than there was in the Blackfoot? Many $\mathrm{BC}$ board members remain in their positions long term. Would their approach remain effective if there was a greater turnover of the participants involved, given the amount of time needed to form a trusting relationship?

\section{References}

Affiliated Tribes of Northwest Indians, Association on American Indian Affairs, Great Plains Tribal Chairman's Association, Inter Tribal Council of Arizona, Native Justice Coalition, Navajo Nation, Oneida Nation of Wisconsin, and Rocky Mountain Tribal Leaders Council. 2021. "Letter to Secretary Deb Haaland."

Ashwood, Loka, Noelle Harden, Michael M. Bell, and William Bland. 2014. "Linked and Situated: Grounded Knowledge." Rural Sociology 79(4):427-52. https://doi. org/10.1111/ruso.12042.

Bell, Michael Mayerfeld. 2004. Farming for Us All: Practical Agriculture and the Cultivation of Sustainability. University Park, PA: Penn State University Press.

Belsky, Jill M. and Alexander Barton. 2018. "Constitutionality in Montana: A Decade of Institution Building in the Blackfoot Community Conservation Area." Human Ecology 46(1):79-89. https://doi.org/10.1007/s10745-018-9967-0.

Bixler, Patrick and Peter Taylor. 2012. "Toward a Community of Innovation in Community-Based Natural Resource Management: Insights from Open Source Software." Human Organization 71: 234-43. https://doi.org/10.17730/humo.71.3.200w0j1266306t79.

Browne-Nuñez, Christine, Treves, Adrian, Voyles, Zachary, Catherine Turng, and MacFarland, David M. 2015. "Tolerance of Wolves in Wisconsin: A Mixed-Methods Examination of Policy Effects on Attitudes and Behavioral Inclinations." Biological Conservation 189:59-71. https://doi.org/10.1016/j.biocon.2014.12.016.

Collins, Harry M. and Robert Evans. 2002. "The Third Wave of Science Studies: Studies of Expertise and Experience." Social Studies of Science 32(2):235-96. https://doi. org/10.1177/0306312702032002003.

Farrell, Justin. 2015. The Battle for Yellowstone: Morality and the Sacred Roots of Environmental Conflict. Princeton: Princeton University Press. 
Fiorino, Daniel J. 1990. "Citizen Participation and Environmental Risk: A Survey of Institutional Mechanisms.” Science, Technology, Ẽ Human Values 15(2):226-43. https: / / doi.org/10.1177/016224399001500204.

Foucault, Michel. 1977. Discipline Eै Punish: The Birth of the Prison. New York: Vintage Books.

Gordon, Heather Sauyaq Jean. 2021. "Ethnographic Futures Research as a Method for Working with Indigenous Communities to Develop Sustainability Indicators." Polar Geography 44(4):233-54. https:/ / doi.org/10.1080/1088937X.2021.1881647.

Haraway, Donna. 1988. "Situated Knowledges: The Science Question in Feminism and the Privilege of Partial Perspective." Feminist Studies 14(3):575-99. https://doi. org/10.2307/3178066.

Harrison, Jill Lindsey. 2011. Pesticide Drift and the Pursuit of Environmental Justice. Cambridge, MA: MIT Press.

Hassanein, Neva and Jack R. Kloppenburg. 1995. "Where the Grass Grows Again: Knowledge Exchange in the Sustainable Agriculture Movement." Rural Sociology 60(4):721-40. https://doi.org/10.1111/j.1549-0831.1995.tb00603.x.

Irwin, Alan. 1995. Citizen Science. Philadelphia: Routledge.

Kellert, Steven R., Jai N. Mehta, Syma A. Ebbin, and Laly L. Lichtenfeld. 2000. "Community Natural Resource Management: Promise, Rhetoric, and Reality." Society E Natural Resources 13(8):705-15. https://doi.org/10.1080/0894192007 50035575.

Kloppenburg, Jack. 1991. "Social Theory and the De/Reconstruction of Agricultural Science: Local Knowledge for an Alternative Agriculture." Rural Sociology 56(4):519-48.

Krings, Amy, Dana Kornberg, and Erin Lane. 2019. "Organizing Under Austerity: How Residents' Concerns Became the Flint Water Crisis.” Critical Sociology 45(4-5):583-97. https://doi.org/10.1177/0896920518757053.

Lute, Michelle L. and Meredith L. Gore. 2014. "Knowledge and Power in Wildlife Management." Journal of Wildlife Management 78(6):1060-68. https://doi. org/10.1002/jwmg.754.

Nelkin, Dorothy. 1975. "The Political Impact of Technical Expertise.” Social Studies of Science 5(1):35-54. https://doi.org/10.1177/030631277500500103.

Robbins, Jim. 2021. "In Montana, Bears and Wolves Become Part of the Culture Wars." New York Times, March 28.

Robbins, Paul. 2006. "The Politics of Barstool Biology: Environmental Knowledge and Power in Greater Northern Yellowstone." Geoforum 37(2):185-99. https://doi. org/10.1016/J.GEOFORUM.2004.11.011.

Skogen, Ketil, Olve Krange, and Helene Figari. 2017. Wolf Conflicts: A Sociological Study. New York: Berghahn.

Skogen, Ketil, Isabelle Mauz, and Olve Krange. 2008. "Cry Wolf!: Narratives of Wolf Recovery in France and Norway.” Rural Sociology 73(1):105-33. https:/ / doi.org/10.1526/00360 1108783575916.

Small, Mario Luis. 2009. “How many cases do i need?’: On science and the logic of case selection in field-based research". Ethnography 10(1):5-38. https://doi. org/10.1177/1466138108099586.

Smith, Linda Tuhiwai. 2012. Decolonizing Methodologies: Research and Indigenous Peoples. 2nd edition. London: Zed Books.

von Essen, Erica. 2017. "Whose Discourse Is It Anyway? Understanding Resistance through the Rise of 'Barstool Biology' in Nature Conservation." Environmental Communication- $a$ Journal of Nature and Culture 11(4):470-89. https://doi.org/10.1080/17524 032.2015.1042986.

Weber, Edward P. 2009. "Explaining Institutional Change in Tough Cases of Collaboration: 'Ideas' in the Blackfoot Watershed." Public Administration Review 69(2):314-27. https://doi.org/10.1111/j.1540-6210.2008.01976.x. 
. 2012. "Unleashing the Potential of Collaborative Governance Arrangements: Getting to Robust Durability in the Blackfoot Valley." Journal of Sustainable Development 5(7):p35. https://doi.org/10.5539/jsd.v5n7p35.

Weber, Max. 1978. Economy and Society: An Outline of Interpretive Sociology. Berkeley: University of California Press.

Weber, Edward P., Belsky, Jill M., Lach, Denise, and Cheng, Antony S. 2014. "The value of practice-based knowledge”. Society E Natural Resources 27(10):1074-88.

Wenger, Etienne. 2000. "Communities of Practice and Social Learning Systems." Organization 7(2):225-46. https://doi.org/10.1177/135050840072002.

Wilson, Seth, Elizabeth Bradley, and Gregory Neudecker. 2017. “"Learning to live with wolves: Community-based conservation in the blackfoot valley of montana." HumanWildlife Interactions 11(3):245-257.

Wilson, Seth M., Neudecker, Gregory A., and Jonkel, James J. 2014. "Human-Grizzly Bear Coexistence in the Blackfoot River Watershed, Montana: Getting Ahead of the Conflict Curve". Pp. 177-214 in Large Carnivore Conservation: Integrating Science and Policy in the North American West. Chicago: University of Chicago Press.

Wynne, Brian. 1992. "Misunderstood misunderstanding: Social identities and public uptake of science". Public Understanding of Science 1(3):281-304. https://doi.org/10.108 8/0963-6625/1/3/004.

- 1996. "May the sheep safely graze? A reflexive view of the expert-lay knowledge divide”. Pp. 44-83 in Risk, Environment and Modernity: Towards a New Ecology, edited by scote Lash Bronislaw Szerszynski and Briget Wynne. London: Sage.

. 2003. "Seasick on the third wave? subverting the hegemony of propositionalism: Response to collins \& evans (2002)". Social Studies of Science 33(3):401-17. https:/ / doi. org/10.1177/03063127030333005. 